\title{
Model Pengkuran Kinerja Lembaga Zakat di Indonesia
}

\author{
Yandi Bastiar \\ yandy.elshaarawy92@gmail.com \\ Efri Syamsul Bahri \\ efrisb@gmail.com \\ Sekolah Tinggi Ekonomi Islam SEBI, Indonesia
}

\begin{abstract}
Seeing the tasks of zakat institutions that are so complex, certainly indicates that the performance of zakat institutions need special attention to be evaluated in terms of management of zakat funds. Because zakat has a strategic role to assist the government in poverty alleviation programs and development programs. This study aims to explain the model of zakat institution performance measurement. The models described in this study consist of National Zakat Index (IZN), Zakat Village Index (IDZ), Center of Islamic Business and Economic Studies (CIBEST), Balance Scorecard, Indonesia Magnificence of Zakat (IMZ) and International Standard of Zakat Management (ISZM). The method used in this study is Library Research, and from the results of this study shows that each measurement model has the characteristics of each with different measurement methods with each other.
\end{abstract}

Keywrds: Performance Measurement, Measurement Model, Zakat Institution

\section{PENDAHULUAN}

Islam adalah agama yang syumuliah (universal) dimana segala aspek kehidupan di atur dalam Islam tanpa terkecuali aspek ekonomi. Dalam Islam, ekonomi mengandung dasar-dasar keutamaan, kebahagiaan dan kesejahteraan bersama serta menghilangkan ketimpangan antara si miskin dan si kaya. Kemiskinan memang selalu menjadi masalah yang tak kunjung usai dan Islam punya solusinya. Dalam pandangan Islam dikenal instrumen ekonomi yang memiliki tujuan untuk memberantas kemiskinan yaitu zakat.

Zakat mempunyai peran penting dalam pemberdayaan ekonomi umat. Namun negara-negara dimana mayoritas penduduknya beragama Islam yang termasuk dalam kategori negara sedang berkembang masih berada pada posisis tingkat kemiskinan yang masih tinggi termasuk negara Indonesia (Miftah, 2008, hlm 313). Perintah zakat dalam Al-Qur'an ditemukan sebanyak 32 kali, 26 kali diantaranya disebutkan bersamaan dengan kata shalat. Hal ini mengisyaratkan bahwa kewajiban mengeluarkan zakat seperti halnya kewajiban mendirikan shalat (Naimah, 2013, hlm 2).

Undang-Undang No 23 tahun 2011 tentang pengelolaan zakat menyebutkan bahwa zakat adalah harta yang wajib dikeluarkan oleh seorang muslim atau badan usaha untuk diberikan kepada yang berhak menerimanya sesuai dengan syariat Islam. Berdasarkan Undang Undang No 23 tahun 2011 tentang pengelolaan zakat 
pengelolaan zakat dilakukan oleh Badan Nasional Zakat Nasional disingkat BAZNAS) dan Lembaga zakat swasta (Lembaga Amil Zakat disingkat LAZ). Menurut Undang Undang tersebut, BAZNAS diberi wewenang untuk mengelola dan mengkoordinasikan semua lembaga zakat. Sedangkan LAZ memiliki wewenang dalam hal hal pengumpulan, distribusi, pengelolaan dan pertanggungjawaban zakat (Beik \& Arsyianti, 2016, hlm 142).

Dengan tugas lembaga zakat yang begitu kompleks, maka kinerja lembaga zakat perlu mendapat perhatian khusus (Beik, 2009, hlm 52 ). Untuk mengukur kinerja suatu lembaga, dalam hal ini lembaga zakat baik BAZNAS maupun LAZ memiliki beberapa model pengukuran yang bisa di gunakan diantaranya Indeks Zakat Nasional (IZN), Indeks Desa Zakat (IDZ), Center of Islamic Business and Economic Studies (CIBEST), Balance Scorecard, Indonesia Magnificence of Zakat (IMZ) dan International Standard of Zakat Management (ISZM). Dalam penelitian ini peneliti akan menjelaskan model model pengukuran kinerja lembaga zakat tersebut.

Berdasarkan uraian di atas, peneliti tertarik untuk melakukan penelitian terhadap model pengukuran kinerja lembaga zakat di Indonesia. Maka penelitian ini di beri judul "Model Pengukuran Kinerja Lembaga Zakat Di Indonesia". Fokus penelitian ini adalah untuk menjelaskan enam model pengukuran kinerja lembaga zakat di Indonesia.

\section{Metode Penelitian}

Dalam penelitian ini, penulis meneliti dengan menggunakan metode studi kepustakaan (library research), yaitu dengan cara mengumpulkan dan mempelajari literatur yang telah ada dari berbagai sumber seperti: jurnal, artikel, buku dan lain lain yang berkaitan dengan penelitian ini. Penelitian ini menggunakan teknik analisis data secara deskriptif sehingga mendapatkan gambaran atau penjelasan dari model pengukuran kinerja lembaga zakat di Indonesia.

\section{TINJAUAN LITERATUR}

\subsection{Zakat}

\subsubsection{Pengertian Zakat}

Secara bahasa kata zakat mempunyai arti, yaitu: keberkahan, pertumbuhan, perkembangan, dan kesucian, secara istilah zakat adalah bagian dari harta dengan persyaratan tertentu yang diwajibkan Allah SWT kepada pemiliknya untuk diserahkan kepada yang berhak menerimanya dengan persyaratan tertentu pula. Dengan demikian pengertian zakat baik secara bahasa dan istilah bahwa harta yang dikeluarkan zakatnya akan menjadi berkah, tumbuh, berkembang dan bertambah, suci dan baik (Prasetyoningrum, 2015, hlm 4).

Makna keberkahan yang terdapat pada zakat berarti dengan membayar zakat akan memberikan berkah kepada harta yang dimiliki. Zakat berarti pertumbuhan karena dengan memberikan hak fakir miskin dan lain-lain yang terdapat dalam harta benda kita, akan terjadilah suatu sirkulasi uang yang dalam masyarakat mengakibatkan berkembangnya fungsi uang itu dalam kehidupan perekonomian di masyarakat. Zakat bermakna kesucian ataupun keberesan yang dimaksudkan 
untuk membersihkan harta benda milik orang lain, yang dengan sengaja atau tidak sengaja, termasuk ke dalam harta benda kita (Nasrullah, 2013, hlm 2).

\subsection{Lembaga zakat}

Dalam pengelolaan dana zakat secara profesional dibutuhkan suatu badan khusus yang bertugas sesuai dengan ketentuan syariah Islam mulai dari perhitungan, pengumpulan, dan pengelolaan zakat hingga pentasyarufannya (Habib, 2016, hlm 2). Di Indonesia terdapat lembaga zakat yang di bentuk oleh pemerintah dan yang di bentuk oleh masyarakat. Adapun lembaga yang di bentuk oleh pemerintah ialah Badan Amil Zakat Nasional yang di singkat BAZNAS dan lembaga yang dibentuk masyarakat ialah Lembaga Amil Zakat atau LAZ.

Badan Amil Zakat Nasional yang selanjutnya disebut BAZNAS adalah lembaga pemerintah yang melakukan pengelolaan zakat secara nasional. BAZNAS berkedudukan di ibu kota dan merupakan lembaga pemerintah nonstruktural yang bersifat mandiri dan bertanggung jawab kepada Presiden melalui Menteri.

Dalam melaksanakan tugasnya BAZNAS menyelenggarakan fungsinya sebgai berikut:

1. Perencanaan pengumpulan, pendistribusian, dan pendayagunaan zakat

2. Pelaksanaan pengumpulan, pendistribusian, dan pendayagunaan zakat

3. Pengendalian pengumpulan, pendistribusian, dan pendayagunaan zakat,

4. Pelaporan dan pertanggungjawaban pelaksanaan pengelolaan zakat.

Lembaga Amil Zakat yang selanjutnya disingkat LAZ adalah lembaga yang dibentuk masyarakat yang memiliki tugas utama membantu BAZNAS dalam pengumpulan, pendistribusian, dan pendayagunaan zakat. Pembentukan LAZ wajib mendapat izin Menteri atau pejabat yang ditunjuk oleh Menteri.

Pengelolaan zakat harus berasaskan syariat Islam, amanah, kemanfaatan, keadilan, kepastian hukum, terintegrasi, dan akuntabilitas. BAZNAS dan LAZ juga harus membuat laporan pelaksanaan pengelolaan zakat, infak, sedekah, dan dana sosial keagamaan lainnya kepada Menteri secara berkala sebagai bentuk pertanggungjawaban BAZNAS dan LAZ menjadi lembaga pengelola zakat. Sehingga kualitas manajemen BAZNAS dan LAZ dapat dievaluasi, dinilai, dan dibandingkan.

\subsection{Kinerja}

\subsubsection{Pengertian Kinerja}

Kinerja diartikan sebagai hasil kerja atau prestasi kerja. Dalam makna yang luas, kinerja juga mencakup bagaimana proses pekerjaan berlangsung (Salomon, Sariatmo, \& Salim 2017), merupakan hasil dari pekerjaan, implementasi tugas dari segala bentuk output yang telah diberikan dalam sebuah tugas atau pekerjaan (Shabri, 2014), merupakan istilah umum yang digunakan untuk menunjukkan sebagian atau seluruh tindakan atau aktivitas dari suatu organisasi pada suatu periode seiring dengan referensi pada sejumlah standar seperti biaya-biaya masa lalu atau yang diproyeksikan suatu dasar efisiensi, pertanggungjawaban atau akuntabilitas manajemen dan semacamnya (Polinggapo, 2014, hlm 3).

Dari beberapa penjelasan diatas, disimpulkan bahwa kinerja suatu organisasi merupakan sesuatu yang dihasilkan oleh suatu organisasi dalam periode tertentu dengan mengacu pada standar yang telah ditentukan. Kinerja organisasi ialah 
suatu hasil yang dapat diukur dengan menggambarkan kondisi suatu organisasi. Pengukuran kinerja organisasi hendaknya mencakup pengukuran terhadap semua aktivitas organisasi baik aktivitas yang dapat diukur secara kualitatif maupun secara kuantitatif.

\subsubsection{Pengukuran Kinerja Lembaga Zakat}

Selama ini, sistem pengukuran kinerja lebih banyak digunakan oleh organisasi komersil seperti perusahaan swasta. Sedangkan organisasi nirlaba seperti halnya Organisasi Pengelola Zakat atau OPZ masih kurang menyadari pentingnya pengukuran kinerja bagi organisasinya. Bagi organisasi komersil pengukuran kinerja bermanfaat bagi peningkatan labanya. Sedangkan bagi organisasi nirlaba, pengukuran kinerja akan sangat bermanfaat bagi pengembangan program kerja dimasa mendatang.

Pada dasarnya, penilaian kinerja suatu organisasi dilakukan agar organisasi yang bersangkutan bisa terus belajar memperbaiki kinerja organisasinya. Jika suatu organisasi terus belajar dalam memperbaiki kinerja organisasinya, maka organisasi tersebut akan tumbuh menjadi organisasi yang sehat dengan kepercayaan publik yang baik.

\subsection{Regulasi Terkait}

Regulasi tentang pengelolaan dan pengelola zakat pada awalnya dituangkan dalam undang-undang No. 38 tahun 1999 tentang pengelolaan zakat. Undangundang tersebut lahir dengan dasar pemikiran zakat merupakan salah satu kewajiban umat Islam, sebagai penduduk mayoritas di Indonesia. Perubahan dilakukan oleh pemerintah dengan ditetapkannya undang-undang No. 23 tahun 2011. Aturan lain terkait zakat termaktub dalam Peraturan Dirjen Pajak No. Per 15/PJ/2012 tanggal 11 Juni 2012 tentang badan atau lembaga penerima sumbangan zakat dan keagamaan sebagai pengurang penghasilan bruto dalam pembayaran pajak. Hingga Oktober 2015 Direktorat Jendral Pajak Kementrian Keuangan mempublikasikan 1 (satu) Badan Amil Zakat Nasional (Baznas), 19 (sembilan belas) lembaga amil zakat dan 2 (dua) badan keagamaan non-Islam yang telah dikukuhkan sebagai penerima zakat dan sumbangan keagamaan (Astuti, 2017, hlm 36).

Undang-undang zakat menempatkan zakat dalam tatanan formal dan hukum nasional, sehingga zakat tidak lagi berada pada ranah tradisional yang dikelola secara parsial tetapi menjadi potensi pendapatan yang harus dikelola secara professional agar mencapai tujuan asasi berupa pemberdayaan masyarakat untuk mencapai kemajuan dan kesejahteraan. Pengaturan zakat dengan sistem hukum yang baku juga memungkinkan zakat terkoneksi dengan aturan pajak dan keuangan (Astuti, 2017, hlm 36).

Selain Undang Undang ada pula regulasi yang berkaitan dalam hal pengukuran dan pencatatan untuk OPZ. Menurut (Rahman, 2015, hlm 154) standar akuntansi ZIS yang berlaku saat ini dan digunakan oleh OPZ sebagai pedoman dalam pembukuan dan pelaporan keuangannya adalah PSAK No. 109 yang dikeluarkan oleh Ikatan Akuntan Indonesia (IAI) pada tahun 2010. Penerbitan PSAK ini telah mengalami proses yang cukup lama kurang lebih empat tahun dari waktu penyusunannya, dimulai dengan disusunnya Eksposure Draft -nya (ED) yang diterbitkan sejak tahun 2008. Namun, saat ini tidak semua 
OPZ yang ada di Indonesia dapat menerapkan PSAK no. 109. Hal tersebut karena sebagian OPZ mengalami beberapa kendala dalam penerapannya. Salah satu faktor kendalanya adalah adanya kesulitan dalam sumber daya manusia yang dimiliki OPZ.

Akuntansi zakat yang ada dalam Pernyataan Standar Akuntansi Keuangan (PSAK) No. 109 bertujuan untuk mengatur pengakuan, pengukuran, penyajian dan pengungkapan transaksi zakat dan infak/sedekah. PSAK ini berlaku untuk amil yakni suatu organisasi/entitas pengelola zakat yang pembentukannya dan pengukuhannya diatur berdasarkan peraturan perundang-undangan yang dimaksudkan untuk mengumpulkan dan menyalurkan zakat dan infak/sedekah, bukan untuk entitas syariah yang menerima dan menyalurkan ZIS tetapi bukan kegiatan utamanya. Untuk entitas tersebut mengacu ke PSAK 101 mengenai Penyajian Laporan Keuangan Syariah. Amil yang tidak mendapatkan izin juga dapat menerapakan PSAK No. 109. PSAK ini merujuk kepada beberapa fatwa MUI (Rahman, 2015, hlm 154).

\subsection{Penelitian Terdahulu}

Tabel 2. 1 Penelitian Terdahulu

\begin{tabular}{|c|c|c|c|c|c|}
\hline No & $\begin{array}{c}\text { Model } \\
\text { Pengukur } \\
\end{array}$ & $\begin{array}{c}\text { Nama } \\
\text { Penulis }\end{array}$ & Judul & Metodologi & Kesimpulan \\
\hline 1 & $\begin{array}{c}\text { Indek Zakat } \\
\text { Nasional (IZN) }\end{array}$ & $\begin{array}{l}\text { Diana, } \\
\text { Irfan } \\
\text { Syauqi } \\
\text { Beik, } \\
\text { Khonsa } \\
\text { Tsabita } \\
(2017)\end{array}$ & $\begin{array}{l}\text { Performance } \\
\text { Analysis of } \\
\text { Zakat } \\
\text { Practices in } \\
\text { East Lampung } \\
\text { Regency using } \\
\text { National Zakat } \\
\text { Index (NZI) }\end{array}$ & $\begin{array}{l}\text { Penelitian ini } \\
\text { mengambil } \\
\text { sampel } 100 \\
\text { rumah tangga } \\
\text { mustahik } \\
\text { dengan teknik } \\
\text { purposive } \\
\text { sampling. Alat } \\
\text { analisis yang } \\
\text { digunakan } \\
\text { adalah Indeks } \\
\text { Zakat Nasional } \\
\text { (IZN) yang } \\
\text { menggunakan } \\
\text { metode estimasi } \\
\text { Bobot Multi- } \\
\text { Stage Weight. }\end{array}$ & $\begin{array}{l}\text { Kinerja praktik } \\
\text { zakat di } \\
\text { Kabupaten } \\
\text { Lampung } \\
\text { Timur berada } \\
\text { pada kategori } \\
\text { kurang baik } \\
\text { dengan nilai } \\
\text { indeks } 0,38 \text {. }\end{array}$ \\
\hline 2 & $\begin{array}{l}\text { Indeks Desa } \\
\text { Zakat (IDZ) }\end{array}$ & $\begin{array}{l}\text { Belum ada } \\
\text { penelitian } \\
\text { yang } \\
\text { mengguna } \\
\text { kan IDZ } \\
\text { sebagai } \\
\text { alat ukur } \\
\text { kinerja. }\end{array}$ & & & \\
\hline 3 & $\begin{array}{l}\text { Center of } \\
\text { Islamic } \\
\text { Business and } \\
\text { Economic } \\
\text { Studies } \\
\text { (CIBEST) }\end{array}$ & $\begin{array}{l}\text { Irfan } \\
\text { Sauqi } \\
\text { Beik \& } \\
\text { Laily Dwi } \\
\text { Arsyianti } \\
\text { (2016) }\end{array}$ & $\begin{array}{l}\text { Measuring } \\
\text { Zakat Impact } \\
\text { On Poverty } \\
\text { And Welfare } \\
\text { Using Cibest } \\
\text { Model }\end{array}$ & $\begin{array}{l}\text { Penelitian ini } \\
\text { mencoba } \\
\text { menganalisis } \\
\text { peran program } \\
\text { zakat berbasis } \\
\text { produktif dalam } \\
\text { mengurangi } \\
\text { tingkat }\end{array}$ & $\begin{array}{l}\text { Hasil yang } \\
\text { tidak terduga } \\
\text { terjadi pada } \\
\text { indeks } \\
\text { kemiskinan } \\
\text { spiritual dimana } \\
\text { ada } \\
\text { peningkatan }\end{array}$ \\
\hline
\end{tabular}




\begin{tabular}{|c|c|c|c|c|c|}
\hline & & & & $\begin{array}{l}\text { kemiskinan } \\
\text { rumah tangga } \\
\text { mustahik (zakat) } \\
\text { dari perspektif } \\
\text { dimensi material } \\
\text { dan spiritual. } \\
\text { Penelitian ini } \\
\text { menggunakan } \\
\text { data primer } \\
\text { yang diperoleh } \\
\text { dari wawancara } \\
\text { melalui } \\
\text { kuesioner di } \\
\text { DKI Jakarta dan } \\
\text { Kabupaten } \\
\text { Bogor. }\end{array}$ & $\begin{array}{l}\text { dua rumah } \\
\text { tangga yang } \\
\text { hidup di bawah } \\
\text { kemiskinan } \\
\text { spiritual. } \\
\text { Artinya, kedua } \\
\text { rumah tangga } \\
\text { penerima zakat } \\
\text { ini lemah dari } \\
\text { segi nilai } \\
\text { spiritual meski } \\
\text { secara material } \\
\text { lebih baik } \\
\text { dengan adanya } \\
\text { program zakat. }\end{array}$ \\
\hline 4 & $\begin{array}{l}\text { Balanced } \\
\text { Scorecard }\end{array}$ & $\begin{array}{l}\text { Seviawati } \\
\text { Polinggap } \\
\text { o (2014) }\end{array}$ & $\begin{array}{l}\text { Pengukuran } \\
\text { Kinerja } \\
\text { Lembaga } \\
\text { Pengelola } \\
\text { Zakat, Infaq } \\
\text { dan Sedekah } \\
\text { (ZIS) dengan } \\
\text { Menggunakan } \\
\text { Metode } \\
\text { Balanced } \\
\text { Scorecard } \\
\text { (Studi Kasus } \\
\text { pada Yayasan } \\
\text { Dana Sosial } \\
\text { Al-Falah } \\
\text { Malang) }\end{array}$ & $\begin{array}{l}\text { Penelitian ini } \\
\text { menggunakan } \\
\text { pendekatan } \\
\text { kualitatif } \\
\text { deskriptif. Data } \\
\text { yang } \\
\text { dikumpulkan } \\
\text { dengan cara } \\
\text { observasi, } \\
\text { wawancara, } \\
\text { kuesioner dan } \\
\text { dokumentasi. }\end{array}$ & $\begin{array}{l}\text { Kinerja YDSF } \\
\text { Malang secara } \\
\text { keseluruhan } \\
\text { sangat baik } \\
\text { ditunjukkan } \\
\text { oleh nilai } \\
\text { scorecard yang } \\
\text { dihasilkan } \\
\text { sebesar 94\%. } \\
\text { Perspektif } \\
\text { Keuangan } \\
\text { sangat baik } \\
\text { karena institusi } \\
\text { tersebut mampu } \\
\text { memenuhi } \\
\text { target realisasi. } \\
\text { Perspektif } \\
\text { pelanggan } \\
\text { menunjukkan } \\
\text { bahwa } \\
\text { kinerjanya } \\
\text { cukup baik } \\
\text { karena layanan } \\
\text { yang diberikan. } \\
\text { Perspektif } \\
\text { proses bisnis } \\
\text { internal } \\
\text { menunjukkan } \\
\text { hasil yang } \\
\text { sangat baik } \\
\text { dalam proses } \\
\text { inovasi yang } \\
\text { dilakukan oleh } \\
\text { organisasi, } \\
\text { hanya dalam } \\
\text { proses operasi } \\
\text { menunjukkan } \\
\text { hasil yang } \\
\text { buruk. }\end{array}$ \\
\hline
\end{tabular}




\begin{tabular}{|c|c|c|c|c|c|}
\hline & & & & & $\begin{array}{l}\text { Perspektif } \\
\text { pembelajaran } \\
\text { dan } \\
\text { pertumbuhan } \\
\text { menunjukkan } \\
\text { hasil yang } \\
\text { sangat baik } \\
\text { karena } \\
\text { hubungan baik } \\
\text { antar karyawan. }\end{array}$ \\
\hline 5 & $\begin{array}{c}\text { Indonesia } \\
\text { Magnificence } \\
\text { of Zakat (IMZ) }\end{array}$ & $\begin{array}{l}\text { Ines } \\
\text { Yuanta } \\
(2016)\end{array}$ & $\begin{array}{l}\text { Penilaian } \\
\text { Kinerja } \\
\text { Lembaga Amil } \\
\text { Zakat Dengan } \\
\text { Pendekatan } \\
\text { Indonesia } \\
\text { Magnificence } \\
\text { of Zakat }\end{array}$ & $\begin{array}{l}\text { Penelitian ini } \\
\text { menggunakan } \\
\text { metode } \\
\text { pengolahan data } \\
\text { berupa } \\
\text { wawancara dan } \\
\text { dokumentasi } \\
\text { secara } \\
\text { triangulasi } \\
\text { sumber dan } \\
\text { triangulasi } \\
\text { teknik. }\end{array}$ & $\begin{array}{l}\text { Kinerja } \\
\text { Kepatuhan } \\
\text { Syariah, } \\
\text { Legalitas, dan } \\
\text { Kelembagaan, } \\
\text { Kinerja } \\
\text { Manajemen, } \\
\text { Kinerja } \\
\text { Keuangan, } \\
\text { Kinerja } \\
\text { Program } \\
\text { Pendayagunaan } \\
\text { dan Kinerja } \\
\text { Legitimasi } \\
\text { Sosial, } \\
\text { menunjukkan } \\
\text { bahwa kinerja } \\
\text { YDSF Cabang } \\
\text { Jember tidak } \\
\text { mengalami } \\
\text { peningkatan } \\
\text { maupun } \\
\text { penurunan } \\
\text { kinerja selama } \\
\text { tahun 2012- } \\
\text { 2014. }\end{array}$ \\
\hline 6 & $\begin{array}{l}\text { International } \\
\text { Standard of } \\
\text { Zakat } \\
\text { Management } \\
\text { (ISZM) }\end{array}$ & $\begin{array}{l}\text { Vivi Sufi } \\
\text { Anggraeni }\end{array}$ & $\begin{array}{l}\text { Komparasi } \\
\text { Kinerja } \\
\text { Keuangan } \\
\text { Badan Amil } \\
\text { Zakat Nasional } \\
\text { dan Lembaga } \\
\text { Amil Zakat } \\
\text { Nasional } \\
\text { Periode 2014- } \\
2016\end{array}$ & $\begin{array}{l}\text { Pengukuran } \\
\text { kinerja } \\
\text { keuangan ini } \\
\text { dilakukan } \\
\text { dengan } \\
\text { menggunakan } \\
\text { rasio keuangan } \\
\text { yang tercantum } \\
\text { dalam ISZM }\end{array}$ & $\begin{array}{l}\text { Dari segi } \\
\text { efisiensi, } \\
\text { lembaga zakat } \\
\text { tersebut dapat } \\
\text { dikatakan telah } \\
\text { efisien dalam } \\
\text { menjalankan } \\
\text { kegiatan } \\
\text { operasionalnya } \\
\text { namun dari segi } \\
\text { kapasitas masih } \\
\text { harus } \\
\text { ditingkatkan. }\end{array}$ \\
\hline
\end{tabular}




\section{PEMBAHASAN}

\subsection{Model-Model Pengukuran Kinerja Lembaga zakat}

Model pengukuran kinerja lembaga zakat ialah alat yang di gunakan suatu institusi atau lembaga yang bergerak dalam hal pengelolaan dana zakat untuk mengukur sejauh mana kinerja lembaga tersebut sehingga dapat dijadikan sebagai bahan evaluasi lenbaga yang bersangkutan agar memperbaiki kinerjanya. Adapun model-model pengukuran kinerja lembaga zakat yang bisa digunakan antara lain: Indek Zakat Nasional (IZN), Indeks Desa Zakat (IDZ), Center of Islamic Business and Economic Studies (CIBEST), Balance Scorecard, Indonesia Magnificence of Zakat (IMZ) dan International Standard of Zakat Management (ISZM).

\subsubsection{Indek Zakat Nasional (IZN)}

Indeks Zakat Nasional (IZN), yang disusun oleh Tim Peneliti Pusat Kajian Strategis (Puskas) BAZNAS, merupakan sebuah indeks komposit yang dibangun dengan tujuan untuk mengukur perkembangan kondisi perzakatan nasional. IZN diharapkan dapat menjadi indikator yang dapat memberikan gambaran sejauh mana zakat telah berperan terhadap kesejahteraan mustahik, dan juga dapat menunjukkan pada tahap apa lembaga zakat telah dibangun, baik secara internal kelembagaan, partisipasi masyarakat, maupun dari sisi dukungan yang diberikan pemerintah (Badan Amil Zakat Nasional, 2016, hlm 8).

Indeks Zakat Nasional (IZN) adalah wujud dari keseriusan untuk mentranformasi zakat agar selalu menuju kearah yang lebih baik. Tentunya untuk membuat pengelolaan zakat lebih baik diperlukan adanya indikator yang tepat yang dapat menggambarkan kinerja zakat secara keseluruhan. IZN pada dasarnya juga merupakan rangkuman dari indek indeks yang ada, dimana indeks-indeks tersbut terbagi menjadi tiga tingkatan perhitungan, yaitu tingkatan dimensi, indikator dan variabel. Setiap dimensi memiliki sejumlah indikator, dan indikatorindikator tersebut memiliki sejumlah variabel. Setelah semuanya dihitung maka akan muncul nilai yang menunjukan bagaimana kondisi suatu lembaga tersebut.

Dari hasil kajian Tim Puskas telah diperoleh komponen IZN yang secara umum dibentuk oleh dua dimensi yaitu dimensi makro dan dimensi mikro. Dimensi makro merefleksikan bagaimana peran pemerintah dan masyarakat secara agregat dalam berkontribusi membangun institusi zakat. Dimensi ini memiliki 3 indikator yaitu regulasi, dukungan anggaran pemerintah (APBN), dan database lembaga zakat. Kecuali regulasi dan dukungan anggaran pemerintah, indikator database lembaga zakat kemudian diturunkan kembali menjadi 3 variabel yaitu: jumlah lembaga zakat resmi, muzaki individu, dan muzaki badan usaha.

Sementara itu dimensi mikro merupakan bagian yang disusun dalam perspektif kelembagaan zakat dan penerima manfaat dari zakat atau mustahik. Secara teknis penyusunan, dimensi mikro memiliki dua indikator yaitu performa lembaga zakat dan dampak zakat terhadap mustahik. Indikator performa lembaga zakat kemudian dibuat lebih terperinci ke dalam 4 variabel yang mengukur performa lembaga dari aspek penghimpunan, pengelolaan, penyaluran, dan pelaporan. Sedangkan indikator dampak zakat merupakan gabungan 5 variabel (Badan Amil Zakat Nasional, 2016, hlm 21). 
Dalam teknik estimasi penghitungan yang dilakukan dalam memperoleh nilai IZN menggunakan metode yang dinamakan Multi-Stage Weighted Index. Metode ini menggabungkan beberapa proses tahapan pembobotan yang telah diberikan pada setiap komponen penyusun index, sehingga pembobotan yang diberikan pada setiap komponen tersebut harus dilakukan bertahap dan bersifat prosedural(Badan Amil Zakat Nasional, 2016, hlm 11)

\subsubsection{Indek Desa Zakat (IDZ)}

Indeks Desa Zakat atau disingkat dengan IDZ merupakan sebuah alat mekanisme yang digunakan untuk mengukur (assessment) kondisi sebuah desa sehingga dapat dikatakan layak atau tidak layak dibantu oleh dana zakat. Oleh karena itu Indeks Desa Zakat ini juga dapat digunakan sebagai alat monitoring dan evaluasi atas proses pengelolaan zakat di suatu desa. Indeks Desa Zakat disusun berdasarkan prinsip Process Oriented yang dapat digunakan oleh organisasi pengelola zakat untuk melihat perkembangan programnya pada proses yang berlangsung. Sehingga penyusunan Indeks Desa Zakat ini diharapkan dapat menjadi referensi bagi organisasi pengelola zakat yang akan atau sedang melaksanakan program pemberdayaan berbasis desa atau komunitas tertentu agar lebih terukur dan integral dalam pengelolaannya (Badan Amil Zakat Nasional, 2017).

Indeks Desa Zakat juga merupakan instrumen yang diharapkan bisa mejadi tolak ukur dalam menjalankan salah satu program BAZNAS yaitu program Zakat Community Development (ZCD/ Program Zakat Berbasis Komunitas atau Desa). Dimana Program ZCD ini bertujuan untuk memperbaiki kondisi ekonomi sekaliagus sosial dan spiritual para penerima manfaatnya.

Adapun salah satu program yang menggunakan pendekatan berdasarkan komunitas, dikembangkan Baznas melalui Zakat Community Development (ZCD) dimana program ekonomi produktif dikembangkan melalui program berbasis kawasan misalnya desa. Baznas telah memiliki indeks desa zakat yang kemudian semua program diarahkan untuk menyukseskan pointer desa zakat (Badan Amil Zakat Nasional, 2017a). 81 titik model desa zakat atau ZCD di Indonesia dan ini dilakukan seluruhnya oleh Baznas pusat dan pada waktu yang sama ZCD juga dilakukan oleh Baznas provinsi dan kabupaten/kota (40 Persen Dana Zakat Disalurkan ke Sektor Produktif, 2017).

Program Zakat Community Development ini diinisiasi oleh BAZNAS dalam memberdayakan masyarakat dengan menyasar komunitas mustahik yang hidup di desa-desa yang tertinggal kesejahteraannya, maupun sarana dan prasarananya. Dengan memberikan bantuan zakat berbasis produktif kepada komunitas maka diharapkan komunitas mustahik ini dapat saling bahu-membahu dalam memanfaatkan dana yang dikelola untuk membantu usaha yang telah dijalankan oleh mereka, seperti bertani, berkebun, berdagang, dan lain-lain. Sehingga, diharapkan kesejahteraan mereka akan meningkat dan tidak hanya dari sisi material, tetapi juga pendidikan, kesehatan, dan spiritual pun ikut meningkat (Badan Amil Zakat Nasional, 2017, hlm 1).

Untuk menjalankan program tersebut, tentunya harus ada penilaian di awal untuk menentukan komunitas di suatu desa tepat untuk diberikan program pemberdayaan oleh BAZNAS. Kemudian diperlukan juga adanya pengukuran 
hasil dari dijalankannya program tersebut atau alat evaluasi. Maka tim Puskas BAZNAS merespon hal tersebuat dengan membuat alat ukur yang di beri nama Indeks Desa Zakat atau IDZ. Secara umum komponen IDZ dibentuk oleh 5 (lima) dimensi yaitu ekonomi, kesehatan, pendidikan, kemanusiaan, dan dakwah sesuai dengan bidang penyaluran zakat yang dilakukan oleh BAZNAS. Masing-masing dimensi tersebut memiliki beberapa variabel dan indikator yang akan menjadi acuan untuk dihitung indeksnya (Zaenal, Astuti, \& Sadariyah, 2017).

\subsubsection{Center of Islamic Business and Economic Studies (CIBEST)}

3.1.3.1 Pengertian Center of Islamic Business and Economic Studies (CIBEST)

Center of Islamic Business and Economic Studies yang disingkat menjadi CIBEST merupakan alat ukur kinerja lembaga zakat dengan cara melihat tingkat kemiskinan suatu daerah dengan pendekatan material dan spiritual. Hal ini didasarkan pada konsepsi bahwa mengukur kemiskinan harus dilakukan secara holistik dan komprehensif. Ini berarti aspek material dan spiritual harus dipertimbangkan. Hal ini sesuai dengan ajaran Islam yang diturunkan dari AlQuran dan Sunnah (Beik \& Arsyianti, 2016).

Misalnya, Al Quran surat Taha ayat 118-120 dan Al Quraisy ayat 3-4 menguraikan beberapa hal yang dianggap sebagai kebutuhan dasar yang harus dipenuhi. Kebutuhan pokok ini terdiri dari kebutuhan untuk melakukan ibadah; kebutuhan makanan, pakaian, tempat tinggal dan kebutuhan keamanan. Dalam konteks ini, kebutuhan yang mendasar adalah kebutuhan material dan kebutuhan spiritual. Ketidakmampuan untuk memenuhi kebutuhan ini akan menempatkan seseorang atau rumah tangga dengan kategori miskin, baik yang miskin secara material, maupun miskin secara spiritual atau pun keduanya (Beik \& Arsyianti, 2016, hlm 144).

Kemiskinan tetap menjadi salah satu masalah utama yang dihadapi oleh sebagian besar negara berkembang termasuk Indonesia. Sejumlah kebijakan telah diperkenalkan di banyak negara untuk mengurangi kemiskinan dan ketidaksetaraan pendapatan. Namun, target global untuk mengurangi jumlah kejadian kemiskinan hingga setengahnya pada tahun 2015 sebagaimana dinyatakan oleh KTT PBB tahun 2000 tampaknya gagal. Krisis keuangan global yang terus berlanjut yang mempengaruhi kinerja ekonomi global tampaknya menjadi salah satu penyebab utama kegagalan ini (Beik \& Arsyianti, 2016, hlm 142).

Pengukuran ini dilakukan atas daras keniscayaan terhadap pengukuran kinerja zakat yang langsung melingkupi atas aspek non material yakni hingga ke dasar aspek spritual (Beik \& Arsyianti, 2016, hlm 144) lebih lanjut pengukuran ini dilakukan pada aspek program zakat yang berifat produktif atau sifatnya lebih kepada pemberdayaan mustahiq zakat, sebagai mana kita ketahui bahwa zakat merupakan salah satu skematik islam yang berfungsi untuk melakukan pemerataan atau pendistribusian potensi baik sifatnya material atau non material bahkan hingga aspek spiritual dari mustahiq zakat (Beik \& Arsyianti, 2015).

Indikator dampak zakat memiliki tiga variabel, yaitu indeks kesejahteraan CIBEST (mengkombinasikan aspek pendapatan material dan kondisi spiritual), modifikasi indeks pembangunan manusia (dampak terhadap pendidikan dan 
kesehatan mustahik) dan kemandirian (terkait sustainabilityatau keberlanjutan sumber pendapatan mustahik pasca program penyaluran zakat.

Menurut Beik \& Arsyianti, (2015) model CIBEST menggunakan rumah tangga sebagai unit analisis dan membagi rumah tangga menjadi empat situasi yang mungkin berkenaan dengan kemampuan mereka dalam memenuhi kebutuhan material dan spiritual.

Pertama, rumah tangga mampu memenuhi kedua kebutuhan, yaitu kebutuhan material dan spiritual sepenuhnya. Ini disebut rumah tangga sejahtera. Mereka hidup di bawah hayatan thayyibah atau kondisi kesejahteraan seperti yang disebutkan oleh Allah SWT dalam QS An Nahl ayat 97

Kedua, sebuah rumah tangga memiliki kapasitas untuk memenuhi kebutuhan spiritual saja, sementara mereka tidak dapat memenuhi kebutuhan material sampai tingkat minimum. Rumah tangga ini hidup di bawah kemiskinan material. Hal ini sejalan dengan pernyataan Allah dalam QS Al Baqoroh ayat 155156. Dalam ayat-ayat ini Allah telah memberikan informasi bahwa beberapa orang akan diuji dengan kekurangan kekayaan, kekurangan buah dan kebutuhan material lainnya. Dengan kata lain, orang-orang ini hidup dalam kondisi kekurangan bahan. Namun, mereka memiliki kondisi spiritual yang kuat, yang ditunjukkan oleh komitmen mereka untuk selalu menyerahkan diri kepada Allah dan untuk menjaga kesabaran dan ketabahan mereka di jalan Allah. Mereka mungkin menderita di dunia ini, tapi mereka akan dihargai oleh Allah di akhirat.

Ketiga, sebagai lawan dari yang kedua, sebuah rumah tangga hanya mampu memenuhi kebutuhan material. Sedangkan untuk kebutuhan spiritual, rumah tangga ini tidak memiliki kemampuan untuk memenuhinya. Rumah tangga ini pada dasarnya hidup di bawah kondisi kemiskinan spiritual. Mengenai hal ini, Allah SWT telah menyebutkan orang-orang semacam ini dalam QS Al An'am ayat 44. Dalam ayat ini, Allah menjelaskan tentang sudah adanya peringatan, namun mereka mampu menghasilkan kelimpahan kekayaan dan uang untuk menunjang kehidupan mereka. Mereka mungkin mendapatkan kesenangan di dunia ini, tapi pasti akan menderita di akhirat jika mereka tidak mengubah kondisi spiritual mereka.

Keempat, rumah tangga tidak mampu memenuhi kebutuhan material dan spiritual. Rumah tangga ini hidup dalam kategori kemiskinan absolut. Hal ini telah dijelaskan oleh Allah dalam QS Taha ayat 124. Mereka yang hidup di bawah kemiskinan mutlak adalah orang-orang yang paling disayangkan, yang menderita di dunia ini dan di akhirat. Oleh karena itu, kelompok masyarakat ini harus diberi perhatian lebih dalam proses pembangunan negara karena mereka mewakili kelompok masyarakat terlemah (Beik \& Arsyianti, 2016, hlm 145-146)

Berdasarkan konsepsi dan tipologi rumah tangga di atas maka disusun formula untuk menghitung indeks kesejahteraan, indeks kemiskinan material, indeks kemiskinan spiritual dan indeks kemiskinan absolut yang berasal dari kuadran CIBEST.

Kuadran CIBEST dibagi menjadi empat kuadran. Rumah tangga yang tinggal di kuadran pertama dianggap sebagai rumah tangga yang kaya material dan spiritual. Hal ini karena rumah tangga dapat secara positif memenuhi kebutuhan material dan spiritual. Dengan menggunakan analisis yang sama, 
diketahui bahwa di kuadran kedua, rumah tangga kaya material dan kaya secara spiritual. Sedangkan kuadran ketiga menunjukkan bahwa rumah tangga yang tinggal di kuadran kaya material dan miskin secara spiritual, sementara kuadran keempat menggambarkan rumah tangga yang secara material dan spiritual miskin. Kecukupan pemenuhan kebutuhan juga berarti bahwa rumah tangga tersebut hidup di atas garis kemiskinan, baik garis kemiskinan material, garis kemiskinan spiritual atau kedua garis (Beik \& Arsyianti, 2015).

\section{Balanced Scorecard}

\section{Pengertian Balanced Scorecard}

Balanced Scorecard berasal dari dua kata yaitu balanced (berimbang) dan scorecard (kartu skor). Balanced (berimbang) berarti adanya keseimbangan antara performance keuangan dan non- keuangan, performance jangka pendek dan performance jangka panjang, antara performance yang bersifat internal dan performance yang bersifat eksternal. Sedangkan scorecard (kartu skor) yaitu kartu yang digunakan untuk mencatat skor performance seseorang. Kartu skor juga dapat digunakan untuk merencanakan skor yang hendak diwujudkan oleh seseorang di masa depan (Prasetyoningrum, 2015, hlm 10)

Mula-mula Balanced Scorecard merupakan konsep yang mulai dikembangkan dalam strategi bisnis. Konsep ini dianggap mampu mengukur kinerja bisnis yang telah dicapai, sehingga diharapkan mampu mempercepat tercapainya tujuan bisnis yang menguntungkan (Laela, 2010). Pada tahun 1990, Robert S. Kaplan dan David P.Norton telah mempopulerkan konsep baru untuk mengukur kinerja suatu manajemen, konsep ini diberi nama Balanced Scorecard (Imelda, 2004, hlm107). Balanced Scorecard adalah suatu konsep manajemen yang menekankan pada pengukuran keuangan dan non keuangan berdasarkan visi dan misi suatu perusahaan. Adanya Balanced Scorecard, dapat digunakan sebagai alat komunikasi dalam suatu perusahaan atau bisnis (Prasetyoningrum, 2015, hlm 11).

Menurut (Imelda, 2004) Balanced Scorecard adalah salah satu alat yang digunakan oleh manager untuk mengukur kinerja suatu bisnis yang dilihat dari empat perspektif. Keempat perspektif itu terdiri dari perspektif keuangan, perspektif pelanggan, perspektif proses bisnis internal, serta perspektif pertumbuhan dan pembelajaran.

Pengembangan model pengelolaan zakat dengan pendekatan Balanced Scorecard yang bersifat teknis, taktis, strategis dan operasional. Balanced Scorecard diciptakan untuk menetapkan goals dan sekaligus melakukan pengukuran atas pencapaiannya, sehingga secara tidak langsung dalam aplikasinya, sistem ini dapat dipakai sebagai alat penetapan strategi keuangan dan strategi manajerial komprehensif yang bersifat taknis-teknis dan operasional dalam rangka revitalisasi lembaga pengelola zakat yang amanah, profesional dan transparan (Prasetyoningrum, 2015).

Pengimplementasian Balance Scorecare pada perusahaan-perusahaan bisnis yang mempunyai sistem manajemen modern yang tersusun dalam perspektif pertumbuhan, proses bisnis internal, kepuasan dan keuangan menggambarkan keseimbangan ukuran finansial dan non finansial, antara indikator lagging dan indikator leading menjadi suatu sistem manajemen yang secara empiris telah 
banyak dipraktekkan pada perusahaan bisnis dalam suatu kerangka kerja manajerial yang dikembangkan oleh peneliti dan diimplementasikan pada lembaga Islam termasuk LAZ (Prasetyoningrum, 2015).

Pengukuran Balanced Scorecard di bagi dalam 4 (empat) perspektif, yaitu perspektif keuangan, pelanggan $(M u z a k k i)$, bisnis internal serta pertumbuhan dan pembelajaran (Laela, 2010) dalam hal ini maka intergarasi program dan model bisnis zakat memiliki karakteristik going concern.

Dalam penggunaan alat ukur Balance Scorecare terhadap lembaga zakat yaitu dengan cara menganalisis data yang diambil dari suatu lembaga zakat yang kemudian masing-masing perspektif akan di dihitung angkanya. Perspektifperspektif itu terdiri dari perspektif keuangan, bisnis internal, pelanggan serta pertumbuhan dan pembelajaran. Adapun penghitungannya sebagai berikut:

Pertama, mengukur kinerja dari perspektif keuangan diukur dengan membandingkan pencapaian sasaran strategis keuangan lembaga dengan target yang telah ditentukan. Pengukuran ini bertujuan untuk mengetahui kinerja suatu perusahaan dari perspektif keuangan. Adapun indikator kinerja lembaga yang diukur dengan menghitung tingkat penerimaan lembaga pada tahun tertentu.

Realisasi Penerimaan

$$
\text { Rumus }=\frac{}{\text { Target Penerimaan }} \times 100 \%
$$

Selain itu kinerja keuangan ini juga diukur dengan membandingkan realisasi penerimaan dan realisasi pengeluaran pada tahun yang dijalani dengan tahun sebelumnya.

Kedua, dalam mengukur kinerja dari perspektif pelanggan meliputi: akuisisi pelanggan, retensi pelanggan, kepuasan pelanggan. Dalam kontek lembaga zakat, pelanggan adalah Muzakki dan mustahik. Sehingga pengukuran yang dilakukan terkait kinerja perspektif pelanggan meliputi : akuisisi muzakki, retensi muzakki dan kepuasan muzakki dan mustahik.

1. Kemampuan Pemerolehan muzakki (akuisisi muzakki): Mengukur tingkat kemampuan lembaga dalam mendapatkan pelanggan (muzakki) baru. Jumlah muzakki baru

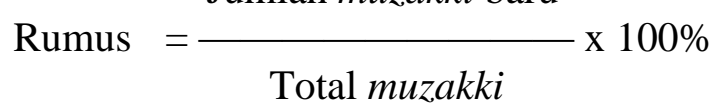

2. Kemampuan mempertahankan Muzakki (Retensi Muzakki): Mengukur tingkat dimana lembaga dapat mempertahankan hubungan dengan pelanggan dalam hal ini muzakki. Jumlah muzakki non aktif dalam 1 periode

$$
\text { Rumus }=\frac{\text { Total jumlah muzakki }}{\text { Tingkat }} \times 100 \%
$$

3. Tingkat kepuasan pelanggan (customer satisfaction) yaitu mengukur seberapa jauh para pelanggan merasa puas terhadap pelayanan perusahaan. Kepuasan konsumen mengukur rata-rata kepuasan pelanggan dengan memberikan nilai pada jawaban kuesioner sesuai dengan tingkat kepuasan yang dirasakan. Dari hasil penjumlahan seluruh nilai yang diperoleh dari seluruh responden akan diketahui pencapaian indeks kepuasan pelanggan sebagai berikut: $61-70$ 


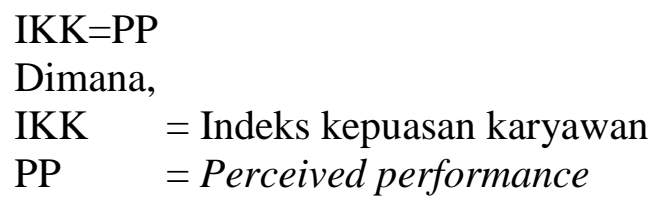

Setelah diketahui IKK dari seluruh responden kemudian digolongkan pada skala a. sangat tidak puas, b. tidak puas, c. netral, d. puas, e. sangat puas. Untuk menentukan nilai skala terlebih dahulu ditentukan indeks kepuasan minimal dan indeks kepuasan maksimal, interval yang dapat dicari dari pengurangan antara indeks kepuasan maksimal dengan kepuasan minimal dibagi menjadi lima dirumuskan sebagai berikut:

IK Maks $=$ R x PP x EX maks

$\mathrm{IK} \operatorname{Min}=\mathrm{R} \times \mathrm{PP} \times \mathrm{EX} \min$

Interval $=(\mathrm{IK}$ maks $-\mathrm{IK} \min )$

Dimana,

$\mathrm{PP} \quad=$ Banyak pertanyaan

$\mathrm{R} \quad=$ Jumlah responden

EX $\min =$ Skor minimal yang diberikan

EX mak = Jum;ah maksimal yang diberikan

Ketiga, mengukur perspektif bisnis internal yang dilakukan meliputi : Inovasi, Operasi, dan layanan. Adapun dalam penelitian ini kinerja perspektif proses bisnis internal dengan mengukur inovasi dan proses operasi dengan ukuran sebagai berikut :

1. Inovasi, yaitu untuk mengetahui jumlah program yang ditawarkan dibandingkan dengan program lembaga yang telah ditargetkan. Pengukuran ini dilakukan dengan melihat data lembaga, inovasi apa yang dikembangkan ada tahun yang bersangkutan.

$$
\text { Inovasi }=\frac{\text { Jumlah Realisasi Inovasi pada } 1 \text { Periode }}{\text { Target Inovasi pada } 1 \text { periode }} \times 100 \%
$$

2. Proses Operasi, yaitu untuk mengetahui kinerja lembaga dalam memaksimalkan produk/jasa yang telah ditawarkan dengan melihat peningkatan perolehan masing-masing produk/jasa.

$$
\text { Operasi }=\frac{\text { Jumlah peningkatan operasi pada } 1 \text { Periode }}{100 \%}
$$

Target operasi pada 1 periode

Terakhir, perspektif pembelajaran dan pertumbuhan bertujuan mendorong lembaga menjadi organisasi belajar (learning Organization) sekaligus mendorong pertumbuhannya. Proses belajar dan perkembangan organisasi bersumber dari tiga prinsip : People, System, dan Organization prosedur' Adapun pengukurannya sebagai berikut :

1. Retensi Karyawan

Mengukur kemampuan lembaga untuk mempertahankan selama mungkin karyawan dengan membandingkan jumlah karyawan yang keluar dengan seluruh jumlah karyawan.

Jumlah karyawan keluar per periode 
Rumus $=\frac{}{\text { Jumlah total karyawan }} \times 100 \%$

2. Produktivitas Karyawan

$$
\text { Rumus }=\frac{\text { Peningkatan penerimaan dana zakat }}{\text { Jumlah total karyawan }} \times 100 \%
$$

3. Peningkatan kepuasan karyawan

Pengukuran dapat dilakukan dengan mengukur tingkat kepuasan karyawan terhadap lembaga. Pengukuran ini dilakukan dengan cara menyebarkan kuesioner kepada karyawan. Kepuasan karyawan, mengukur rata-rata kepuasan karyawan dengan memberikan nilai pada jawaban kuesioner sesuai dengan tingkat kepuasan yang dirasakan dari hasil penjumlahan seluruh nilai yang diperoleh dari seluruh responden akan diketahui pencapaian indeks kepuasan karyawan sebagai berikut:

$\mathrm{IKK}=\mathrm{PP}$

Dimana,

IKK = Indeks kepuasan karyawan

$\mathrm{PP}=$ Perceived performance

Setelah diketahui IKK dari seluruh responden kemudian digolongkan pada skala a. sangat tidak setuju, b. tidak setuju, c. netral, d. setuju, e. sangat setuju. Untuk menentukan nilai skala terlebih dahulu ditentukan indeks kepuasan minimal dan indeks kepuasan maksimal, interval yang dapat dicari dari pengurangan antara indeks kepuasan maksimal dengan kepuasan minimal dibagi menjadi lima dirumuskan sebagai berikut:

$\mathrm{IK}$ Maks = R x PP x EX maks

$\mathrm{IK}$ Min $=\mathrm{R} \times \mathrm{PP} \times \mathrm{EX} \min$

Interval $=(\mathrm{IK}$ maks $-\mathrm{IK} \min )$

Dimana,

$\mathrm{PP} \quad=$ Banyak pertanyaan

$\mathrm{R} \quad=$ Jumlah responden

EX $\min =$ Skor minimal yang diberikan

EX mak = Jum;ah maksimal yang diberikan (Polinggapo, 2014, hlm 3-7)

Penelitian yang menggunakan Balanced Scorecard untuk mengukur kinerja lembaga zakat ialah penelitian yang di buat oleh Seviawati Polinggapo pada tahun 2014 dengan judul "Pengukuran Kinerja Lembaga Pengelola Zakat, Infaq dan Sedekah (ZIS) dengan Menggunakan Metode Balanced Scorecard (Studi Kasus pada Yayasan Dana Sosial Al-Falah Malang)". Penelitian berusaha untuk mengetahui keuntungan dari organisasi Yayasan Dana Al-Falah Malang dengan metode Balanced Scorecard. Penelitian menunjukkan bahwa kinerja YDSF Malang secara keseluruhan sangat baik, ditunjukkan oleh nilai scorecard yang dihasilkan sebesar 94\%. Perspektif keuangan dengan menilai hasil yang sangat baik karena institusi tersebut mampu memenuhi target realisasi. Perspektif pelanggan menunjukkan bahwa kinerjanya cukup baik karena layanan yang diberikan, kesabaran karyawan dan kemudahan penyaluran dana yang diamanatkan melalui berbagai program dan layanan inovatif hingga mustahik melalui kegiatan keagamaan. Perspektif proses bisnis internal menunjukkan hasil 
yang sangat baik dalam proses inovasi yang dilakukan oleh organisasi, hanya dalam proses operasi menunjukkan hasil yang buruk. Perspektif pembelajaran dan pertumbuhan menunjukkan hasil yang sangat baik karena hubungan baik antara karyawan dan pengusaha atau rekan kerja.

\subsubsection{Indonesia Magnificence of Zakat (IMZ)}

\subsubsection{Pengertian Indonesia Magnifinance of Zakat (IMZ)}

Indonesia Magnifinance of Zakat atau IMZ adalah sebuah lembaga konstitusi pemberdayaan dan manajemen organisasi nirlaba yang bergerak dalam bidang pelatihan, konsultasi, dan pendampingan serta riset advokasi di bidang zakat, kemiskinan, dan pemberdayaan. Setiap tahunnya (dimulai tahun 2010), IMZ rutin melakukan penelitian mengenai zakat dan diterbitkan dalam sebuah buku yang berjudul IZDR (Indonesian Zakat and Development Report) salah satu penelitian yang dilakukan adalah mengenai kinerja Organisasi Pengelola Zakat (OPZ) (Supriyatin 2017, hlm 61).

Awal mulanya pada tahun 2010, PEBS-FEUI bekerja sama dengan IMZ melakukan pengukuran kinerja OPZ dan mempublikasikan hasilnya dalam IZDR 2010 (Indonesia Zakat \& Development Report). Kemudian pada tahun 2011, IMZ menerbitkan buku IZDR 2011 dengan menambah kriteria kinerja manajemen yang menilai tiga aspek penting, yaitu penghimpunan, pendayagunaan, dan manajemen. Penilaian kinerja dengan pendekatan IMZ dapat menilai kinerja Organisasi Pengelola Zakat secara komprehensif. Penjabaran penilaian ke dalam lima komponen yang lebih spesifik merupakan kelebihan bagi metode ini jika dibandingkan dengan metode pengukuran kinerja lainnya. Metode pengukuran kinerja OPZ oleh IMZ dengan menggunakan lima komponen pengukuran yang digunakan pada tahun 2011.

Pertama, Kinerja Kepatuhan Syariah, Legalitas, dan Kelembagaan. Penilaian untuk komponen ini terkait dengan: Dewan Pengawas Syariah (DPS), visi dan misi, struktur organisasi, tingkat pendidikan pegawai, program diklat reguler dan persentase pegawai full time. Kedua, Kinerja Manajemen. Penilaian untuk komponen ini terkait dengan Standar Operasional Prosedur (SOP), rencana strategis, penilaian prestasi kerja amil. Ketiga, Kinerja Keuangan. Penilaian untuk komponen ini terkait dengan Laporan keuangan, Efisiensi keuangan dan Kapasitas organisasi.

Keempat, Kinerja Program Pendayagunaan. Penilaian untuk komponen ini terkait dengan Kualitas program pendayagunaan zakat, Program ekonomi produktif, Pendampingan dan Pelatihan. Kelima, Kinerja Legitimasi Sosial. Penilaian untuk komponen ini terkait dengan Biaya promosi, Biaya sosialisasi dan edukasi, Biaya advokasi. (Yuanta, 2016)

International Standard of Zakat Management (ISZM) Pengertian International Standard of Zakat Management (ISZM)

International Standard of Zakat Management (ISZM) adalah salah satu standar internasional dalam pengelolaan zakat oleh lembaga zakat. ISMZ juga merupakan instrumen yang dilakukan dengan diskusi kelompok fokus semua bagian internal organisasi zakat melalui diskusi sistematis dan hasil analisis. ISZM ditujukan untuk membantu semua lembaga zakat dalam menilai kinerja sistem zakat dan memberikan masukan ke dalam agenda reformasi suatu lembaga 
zakat. Tujuan dari pengukuran ini adalah untuk mengidentifikasi sifat dan tingkat kelemahan pengelolaan zakat. Hasil dari perhitungannya akan menjadi dasar untuk memulai strategi perbaikan di semua aspek manajemen (World Zakat Forum dan Indonesia Magnificence of Zakat, 2017).

\section{Sejarah dan Karakteristik}

Banyak laporan menggambarkan kesenjangan yang lebih luas antara orang kaya dan orang miskin yang menjadi semakin kuat. Ada kebutuhan yang jelas untuk memiliki mekanisme alternatif yang mampu meminimalkan kesenjangan tersebut. Secara umum, tingkat kemiskinan di negara-negara mayoritas muslim, yaitu Negara-Negara Anggota OKI masih tinggi dibandingkan dengan negara lain dan rata rata Negara tersebut termasuk kelompok Negara berkembang. Saat ini diperkirakan ada 1,6 miliar orang yang hidup dalam kondisi kemiskinan. Lima puluh empat persen penduduk miskin tinggal di Asia Selatan sementara tiga puluh satu persen berasal dari Afrika Sub-Sahara dan mayoritas penduduk di daerah ini beragama Islam (World Zakat Forum dan Indonesia Magnificence of Zakat, 2017).

Menanggapi situasi tersebut, komunitas zakat dunia ambil bagian dalam solidaritas global untuk tindakan kemanusiaan guna merevitalisasi posisi muslim dalam memperkuat pengaruh muslim dunia, dan untuk mengatasi kecenderungan stereotip sebagai bagian dari kampanye global untuk menghidupkan kembali pemuliaan Islam.

Terlepas dari masalah ini, mekanisme zakat masih perlu mendapat perhatian serius untuk mencari solusi terkait dengan pemahaman fiqih, model manajemen, distribusi zakat antar Negara, mekanisme kerja sama dalam praktik zakat yang berkaitan dengan masalah diplomatik, dan isu-isu terkait lainnya. Maka kehadiran ISMZ berusaha menjadi solusi dari masalah tersebut.

Adanya ISZM menjadi salah satu standar internasional dalam pengelolaan zakat oleh lembaga zakat. ISMZ memiliki tujuan spesifik yang berkaitan dengan program pengembangan manajemen zakat sebagai berikut:

Mengikuti pedoman pengelolaan zakat

Bertindak sebagai alat ukur untuk menilai kualitas pengelolaan zakat.

Bertindak sebagai norma dasar untuk membandingkan tingkat kualitas antara satu organisasi zakat dengan yang lain.

Mendorong peningkatan kelembagaan dan peningkatan efektivitas.

Mendorong organisasi belajar dan amilin (orang).

Implementasi standar stimulasi pengembangan manajemen zakat dari ISMZ memiliki karakteristik sebagai berikut:

Praktis berorientasi

Dapat diterapkan ke semua institusi zakat

Bisa diaplikasikan ke seluruh negara

Bertindak sebagai tata kelola amil yang baik

Untuk bertindak sebagai standar minimum yang komprehensif

Untuk menilai kinerja manajemen puncak pengelolaan zakat, maka dilakukan penelaahan terhadap tujuh aspek ke dalam lingkup ISZM, yang mencakup antara lain: kepatuhan terhadap syariah, kepemimpinan, pengumpunan, keuangan, penyaluran, sistem manajemen dan manajemen amil. 


\section{Analisis Kelebihan dan kekurangan}

Dari pemaparan yang sudah di jelaskankan di atas, bisa di lihat bagimana karakteristik dari setiap alat ukur yang ada. Tentunya dari setiap alat ukur ini tidak ada yang sempurna, akan terdapat kelebihan dan kekurangan di dalamnya. Berikut adalah penjelsan mengenai kelebihan dan kelemahan dari masing-masing alat ukur yang telah di bahas:.

Tabel 3. 1 Analisis Kelebihan dan kekurangan

\begin{tabular}{|c|c|c|}
\hline $\begin{array}{c}\text { Model } \\
\text { Pengukur }\end{array}$ & kelebihan & Kekurangan \\
\hline \multirow{5}{*}{ IZN } & $\begin{array}{l}\text { 1. Hasil dari indeks IZN } \\
\text { menggambarkan } \\
\text { keadaan secara nasional. }\end{array}$ & $\begin{array}{l}\text { 1. Apabila integrasi lembaga } \\
\text { satu dengan lembaga lainnya } \\
\text { kurang baik, sangat } \\
\text { dimungkinkan biaya besar } \\
\text { karena bersifat nasional. }\end{array}$ \\
\hline & $\begin{array}{l}\text { 2. Apabila terciptanya } \\
\text { integrasi data antar unit } \\
\text { lembaga zakat maka indeks ini } \\
\text { dimungkinkan biaya lebih } \\
\text { efesien. }\end{array}$ & $\begin{array}{l}\text { 2. Indeks IZN tergantung pada } \\
\text { IDZ, CIBEST dan Balance } \\
\text { Scorecard sebagai model ukur } \\
\text { penunjang IZN. }\end{array}$ \\
\hline & $\begin{array}{l}\text { 3. Ruang lingkup IZN } \\
\text { mencakup makro dan mikro } \\
\text { yang menggambarkan output } \\
\text { dan input lembaga zakat. }\end{array}$ & \\
\hline & $\begin{array}{l}\text { 4. IZN merupakan alat ukur } \\
\text { pertama di dunia dalam } \\
\text { perzakatan. }\end{array}$ & \\
\hline & $\begin{array}{l}\text { 5. Dapat mendorong kinerja } \\
\text { zakat secara nasional apabila } \\
\text { diimplementasikan dengan } \\
\text { baik }\end{array}$ & \\
\hline \multirow{3}{*}{ IDZ } & $\begin{array}{l}\text { 1. Indeks yang dihasilkan IDZ } \\
\text { menggambarkan pada program } \\
\text { yang ditujukan }\end{array}$ & $\begin{array}{l}\text { 1. Tidak semua desa dapat di } \\
\text { jadikan objek penelitian, karna } \\
\text { di lakukan pada desa yang } \\
\text { sudah menerima } \\
\text { pemberdayaan zakat. }\end{array}$ \\
\hline & $\begin{array}{l}\text { 2. IDZ dapat difungsikan } \\
\text { sebagai kajian dampak atau } \\
\text { evaluasi dan kajian observasi. }\end{array}$ & $\begin{array}{l}\text { 2. Biaya operasional terhitung } \\
\text { mahal, karna membutuhkan } \\
\text { data primer }\end{array}$ \\
\hline & $\begin{array}{l}\text { 3. IDZ menggambarkan suatu } \\
\text { desa. }\end{array}$ & $\begin{array}{l}\text { 3. IDZ tergantung pada } \\
\text { kualitas peneliti dan observer } \\
\text { dalam pelaksanaannya }\end{array}$ \\
\hline
\end{tabular}




\begin{tabular}{|c|c|c|}
\hline \multirow{4}{*}{ CIBEST } & 1. Menyentuh aspek spiritual & $\begin{array}{l}\text { 1. Karna objek penelitian } \\
\text { kecil, di munkinkan memakan } \\
\text { biaya yang mahal tidak } \\
\text { efesien. }\end{array}$ \\
\hline & $\begin{array}{l}\text { 2. Hasil penelitian bisa } \\
\text { terfokus }\end{array}$ & $\begin{array}{l}\text { 2. Apabila data di ambil dari } \\
\text { BPS tidak menggambarkan } \\
\text { kondisi mustahik. }\end{array}$ \\
\hline & $\begin{array}{l}\text { 3. Memiliki faktor yang } \\
\text { menggambarkan keadaan } \\
\text { mustahik }\end{array}$ & $\begin{array}{l}\text { 3. CIBEST hanya slah satu } \\
\text { model dampak, sehingga hasil } \\
\text { penelitian bersifat parsial. }\end{array}$ \\
\hline & $\begin{array}{l}\text { 4. Sebagai salah satu kajian } \\
\text { dampak yang memiliki } \\
\text { indikator lengkap }\end{array}$ & \\
\hline \multirow{2}{*}{$\begin{array}{l}\text { Balance } \\
\text { Scorecard }\end{array}$} & 1. Akses data lebih mudah. & $\begin{array}{l}\text { 1. Hanya menggambarkan } \\
\text { kondisi kelembagaan, tidak } \\
\text { menggambarkan kondisi di } \\
\text { lapangan. }\end{array}$ \\
\hline & $\begin{array}{l}\text { 2. Dapat menilai dari aspek } \\
\text { keuangan, pertumbuhan, } \\
\text { muzakki, mustahik dan } \\
\text { program. }\end{array}$ & \\
\hline $\begin{array}{c}\text { Indonesia } \\
\text { Magnifinance of } \\
\text { Zakat (IMZ) }\end{array}$ & $\begin{array}{l}\text { 1. IMZ dapat menilai kinerja } \\
\text { Organisasi Pengelola Zakat } \\
\text { secara komprehensif. }\end{array}$ & $\begin{array}{l}\text { Hanya terfokus pada } \\
\text { pengukuran terkait } \\
\text { kelembagaan tidak } \\
\text { menggambarkan kondisi di } \\
\text { lapangan. }\end{array}$ \\
\hline $\begin{array}{l}\text { International } \\
\text { Standard of } \\
\text { Zakat } \\
\text { Management } \\
\text { (ISZM) }\end{array}$ & $\begin{array}{l}\text { 1. Menilai kinerja dari } \\
\text { berbagai aspek internal } \\
\text { organisasi. }\end{array}$ & $\begin{array}{l}\text { Terfokus pada pengukuran } \\
\text { terkait internal organisasi tidak } \\
\text { menggambarkan kondisi di } \\
\text { lapangan. }\end{array}$ \\
\hline
\end{tabular}

\section{KESIMPULAN}

Penelitian ini bertujuan untuk menjelaskan model pengukuran kinerja lembaga zakat di Indonesia. Penelitian ini menjelaskan enam model pengukuran kinerja lembaga zakat yang ada di Indonesia yaitu Indeks Zakat Nasional (IZN), Indeks Desa Zakat (IDZ), Center of Islamic Business and Economic Studies (CIBEST), Balance Scorecard, Indonesia Magnificence of Zakat (IMZ) dan International Standard of Zakat Management (ISZM).

Berdasarkan penjelasan di atas, maka dapat disimpulkan bahwa setiap model pengukuran memiliki karakteristik masing-masing dengan metode pengukuran yang berbeda satu sama lain dan hasil dari penelitian ini menunjukan bahwa kinerja lembaga zakat dapat diukur dengan menggunakan beberapa metode antara lain: Pengukuran model Indeks Zakat Nasional (IZN, Pengukaran menggunakan Indeks Desa Zakat (IDZ, Model pengukuran Center of Islamic 
Business and Economic Studies (CIBEST), Pengukuran Balance Scorecard, Indonesia Magnifinance of Zakat (IMZ), Model pengukuran International Standard of Zakat Management atau ISZM. Ssemua model ini perlu dilakukan kajian secara komprehensif satu sama lain agar masing masing konsep dapat melakukan penyelarasan sesuai dengan ruang lingkup yang dilakukan sehingga terciptanya suatu manfaat atas data yang diterima dari penelitian secara maksimal. Saran

Penyelarasan dalam setiap metode pengukuran dan spesifikasi target penggunaan di lembaga zakat sangat penting dilakukan agar hasil yang diharapkan dapat berbuah maksimal. Selain dari itu integrasi juga bisa dilakukan dengan menggunakan wewenang dan fungsi Badan Amil Zakat Nasional sebagai regulator dalam lembaga lembaga zakat. Berbagai hal yang dapat dimanfaatkan dalam modeling dan konsep pengukuran kinerja zakat hendaknya dilakukan pemutakhiran modeling yang digunakan atau semua modeling dilakukan dengan menyelaraskan. Hal ini sangat penting apabila seluruh stakeholder lembaga zakat kedepanya dilakukan kewajiban atas laporan govermentnya seperti pengukuran yang dilakukan.

Kami berharap kedepanya bisa dilakukan penelitian lebih lanjut karena penulis menyadari keterbatasan penelitian yang dilakukan tidak sampai spesifik menjelaskan tentang metode mana yang digunakan dan layak untuk lembaga zakat dengan concern zakat saja atau zakat produktif atau program lainya. 


\section{DAFTAR PUSTAKA}

Astuti, M. (2017). Akuntabilitas Dan Transparansi Pelaporan, Jurnal Akuntansi Bisnis Vol. 10 No. 1. 10(1), 31-53.

Badan Amil Zakat Nasional. (2016). Indeks Zakat Nasional. Puskas Baznas. ISBN: 978-602-60689-1-0

Badan Amil Zakat Nasional. (2017). Indeks Desa Zakat. Puskas Baznas. ISBN: 978-602-6

Badan Amil Zakat Nasional. (2017). Outlook Zakat Indonesia. Puskas Baznas. ISBN: 978-602-60689-0-3

Beik, I. S. (2009). Analisis Peran Zakat Dalam Mengurangi Kemiskinan: Studi Kasus Dompet Dhuafa Republika. Zakat \& Empowering - Jurnal Pemikiran Dan Gagasan, 2, 45-53.

Beik, I. S., \& Arsyianti, L. D. (2015). Construction of Cibest Model As Measurement of Poverty and Welfare Indices From Islamic Perspective. AlIqtishad: Journal of Islamic Economics, 7(1), 87-104. https://doi.org/10.15408/ijies.v7i1.1361

Beik, I. S., \& Arsyianti, L. D. (2016). Measuring Zakat Impact on Poverty and Welfare Using CIBEST Model. Journal of Islamic Monetary Economics and Finance, 1(2), 141-160.

Habib, A. A. (2016). The Principle of Zakat, Infaq, and Shadaqah Accounting Based SFAS 109. Journal of Acounnting and Bussines, 1(1), 21-37.

Hilmiyah, L. U., \& Beik, I. S. (2017). National Zakat Index (NZI) Measurement on Zakat Management in Bogor Regency 2016, Journal Ijaz Baznas (9), 6014.

Imelda, R. H. . (2004). Implementasi Balanced Scorecard Pada Organisasi Publik. Jurnal Akuntansi Dan Keuangan, 6(Gaspersz 2003), 106-122. https://doi.org/10.9744/jak.6.2.pp. 106-122

Laela, S. F. (2010). Analisis Faktor-Faktor Yang Mempengaruhi Kinerja Organisasi Pengelola Zakat. Islamic Finance \& Business Review, 5(2), 126146.

Lestari, P. (2010). Pengukuran Kinerja Badan Amil Zakat Daerah (BAZDA) Kabupaten X Perspektif Balanced Scorecard. Jurnal Investasi, 6(1), 1-13.

Miftah, A. (2008). Pembaharuan Zakat untuk Pengentasan Kemiskinan di Indonesia. Innovatio, VII(14), 313-330.

Naimah. (2013). Konsep Hukum Zakat Sebagai Instrumen dalam Meningkatkan Perekonomian Umat. Jurnal Syariah Vol 14,No1 (2014) ISSN 1412-6303

Nasrullah, M. (2013). Peranan Zakat Sebagai Pendorong Multiplier Ekonomi. Jurnal Hukum Islam, 1-8. Retrieved from http://e-journal.stainpekalongan.ac.id/index.php/Hukum/article/view/296

Polinggapo, S. (2014). Pengukuran Kinerja Lembaga Pengelola Zakat Infaq dan Sedekah Dengan Menggunakan Metode Balance Scorecard. E-theses Universitas Islam Negri Maulana Malik Ibrahim Malang.

Prasetyoningrum, A. K. (2015). Pendekatan Balance Scorecard Pada Lembaga Amil Zakat Di Masjid Agung Jawa Tengah. Economica: Jurnal Pemikiran Dan Penelitian Ekonomi Islam, VI(1), 1-36. 
https://doi.org/10.21580/economica.2015.6.1.784

Rahman, T. (2015). Akuntansi Zakat, Infak dan Sedekah (PSAK 109): Upaya Peningkatan Transparansi dan Akuntabilitas Organisasi Pengelola Zakat (OPZ). Jurnal Muqtasid, 6(109), 141-164.

Salomon, L. L., Sariatmo, M. A., Salim G. G., 2017. Pengukuran Kinerja Perusahaan Berbasis Model Smart System (Studi Kasus Perusahaan Manufaktur Gaharu). Jurnal Teknik dan Ilmu Komputer. Vol. 06 No 23 2017

Supriyatin,D 2017. Analisis Penerapan Internet Reporting Dan Penilaian Kinerja Keuangan Organisasi Pengelola Zakat. repository.uinjkt.ac.id 2017

Shabri, H. (2014). Performance Comparison Amil Zakat Institutions Managed By The Government And Private Organization In West Sumatra Province, Volume 1(Performance), 103-117.

Undang-Undang Republik Indonesia No.23 Tahun 2011. (2011). Tentang Pengelolaan Zakat. Jakarta: Dewan Perwakilan Rakyat (DPR).

World Zakat Forum dan Indonesia Magnificence of Zakat. (2017). Dalam Juwaini, et.al (Penyunt.), International Standard of Zakat Management ISZM: 2017. Jakarta: IMZ Publisihing.

Yuanta, I. (2016). Penilaian Kinerja Lembaga Zakat Dengan Pendekatan Indonesia Magnificence of Zakat. repository.unej.ac.id 2016.

Zaenal, M. H., Astuti, A. D., \& Sadariyah, A. S. (2017). Increasing Urban Community Empowerment through Changing of Poverty Rate Index on the Productive Zakat Impact Increasing Urban Community Empowerment through Changing of Poverty Rate Index on the Productive Zakat Impact. Puskas Baznas Working Paper Series Working Paper no. 14 10(1), 31-53 (14). 